\title{
Research on the Effect of Monetary Policy on Financial Accelerator-- Based on the empirical analysis of Chinese steel enterprises
}

\author{
Chenyi Zhao ${ }^{1 *}$,a, Xuefei $\mathrm{Yu}^{2, \mathrm{~b}}$ \\ ${ }^{1}$ Wuhan university of technology, Wuhan, China \\ ${ }^{2}$ Changjiang Futures Co. LTD, Wuhan, China
}

\begin{abstract}
From the perspective of principal-agent, the theory of financial acceleration holds that due to the defects of the financial market, external shocks will be amplified by the financial market and accelerate the transmission in the real economy, and the impact on small enterprises is greater than that on large enterprises. According to the theory of financial deceleration, the agency cost caused by financial friction is countercyclical, which restrains credit scale to some extent, prevents excessive debt, and thus alleviates external shocks. According to the empirical analysis of panel data of iron and steel enterprises and the existing empirical results of the real estate industry, it is found that there is no financial accelerator effect or financial reducer effect in the field of iron and steel enterprises. China's financial accelerator is more focused on bubbly assets where growth is expected and continues to be overheated despite policy tightening. That would trigger a bigger debt crisis and greater economic volatility.
\end{abstract}

\section{Introduction}

In 2008, under the influence of national monetary policy control and domestic and foreign situations, the real estate industry once fell into a serious contraction situation. In 2009 , under the influence of multiple factors such as loose monetary policy, the real estate market in major cities rose in both quantity and price, and quickly turned from recovery to overheating. The empirical analysis shows that the acceleration effect of monetary policy and finance in China is quite significant in the real estate industry. In the energy, material, industrial and other industries, how to use the efficiency of the financial accelerator effect to achieve a balance between economic growth and the prevention of real estate bubbles is what the government must take into account when implementing monetary policy.

\section{Foreign financial accelerator effect theory}

\subsection{Financial accelerator effect theory}

Bernanke, Gertler, and Gilchrist (1996) believed that corporate financial conditions would have an effect on economic cycle fluctuations, and changes in financing agency costs would increase the impact on the economy
[1]. They call this phenomenon a financial accelerator. The following is the transmission mechanism of monetary policy ( $>>$ represents financial acceleration):

$$
\begin{aligned}
\mathrm{M} \uparrow \rightarrow \mathrm{R} \downarrow & \rightarrow \mathrm{P} \uparrow \\
\text { Crisis }>>>\mathrm{Na} \uparrow & \rightarrow \mathrm{Loan} \uparrow \rightarrow(\mathrm{I} \downarrow \rightarrow \mathrm{I} \uparrow \rightarrow \mathrm{Y} \downarrow)
\end{aligned}
$$

Kiyotaki and Wright (1997) called the above impact amplification mechanism static multiplier effect, and the effect caused by credit market defects is a dynamic multiplier effect, which is much greater than the former [2].

Kiyotaki and Moore (1991) pointed out earlier that the premium of external financing is an important part of agency cost [3]. If companies are hit negatively and their balance sheets deteriorate, the credit lines they receive will be reduced. The negative impact will reduce corporate earnings, increase costs, reduce net asset value and increase financial leverage, thus worsening financing conditions of enterprises.

\subsection{Theory of financial speed reduction effect}

Bacchetta and Camillo (2000), through a dynamic General equilibrium model (DSGE) analysis, believed that capital market defects were shock absorber, which slowed down real economy fluctuations, rather than accelerators [4]. Bhakta and Camillo's theory can be summarized as follows:

$\nearrow$ Loan $\uparrow$ (prosperous company) $\rightarrow(\mathrm{I} \uparrow \rightarrow \mathrm{Y} \uparrow)$

\footnotetext{
${ }^{*}{ }^{2}$ zhaochenyi1009@outlook.com, ${ }^{\mathrm{b}} 1037536042 @ q q . c o m$
} 


$$
\begin{aligned}
\mathrm{M} \uparrow \rightarrow \mathrm{R} \downarrow \rightarrow \quad(\mathrm{P} \uparrow \rightarrow \mathrm{Na} \uparrow) \\
\searrow \text { Loan } \downarrow \quad(\text { restrained company }) \rightarrow(\mathrm{I} \uparrow \rightarrow \mathrm{Y} \uparrow)
\end{aligned}
$$

Elul (2006) put forward the financial reducer theory with "judicial defects" as the core: if the borrower defaults, the difference between the outstanding loan of the borrower and the value of liquid assets could have been offset by the assets of the borrower and the guarantor or the forward income [5]. But because the law limits the bank's liquidation right to the borrower, it is difficult for the bank to make up for the loan loss through the liquidation [6].

The current research is based on the premise of enterprise homogenization [7]. This paper believes that although there is a financial acceleration effect, the effectiveness of monetary policy transmission channels between industries is different. Therefore, it is necessary to quantify this acceleration effect to implement heterogeneous monetary policies to adjust the industry structure.

\section{The empirical consistency of the domestic financial accelerator effect}

The financial accelerator effect of monetary policy in China is obvious, but different models are used to verify this theory.

Zhao Zhenquan, Yu Zhen, and Liu Miao (2007) used the threshold vector auto regression (TVAR) model to conduct empirical research on the nonlinear correlation between China's credit market and macroeconomic fluctuations at the macro level [8]. It is found that there was a significant financial accelerator effect in China. The response of economic fluctuations in the "tightening" state of the credit market was significantly stronger than that in the "loosening" state of the credit market.

Yuan Shenguo and Liu Lanfeng (2009) use SUR measurement method empirical analysis. Their research results show that the financial accelerator in the manufacturing metal conduction effect most strongly [9].

Wang Manyi and Liu Tongshan (2010) tested the financial accelerator mechanism in China's real estate industry utilizing regression analysis [10]. Their results also confirm that the impact faced by large enterprises and small enterprises is asymmetric.

Wang Chuan, Li Xin and Zhou zhengfeng (2011) simulated the quarterly data of DSGE model of the "financial accelerator", they found that the influence of asymmetric information in credit markets and the macroeconomic variables showed greater volatility [11].

The data in the paper can see that the direction of China's monetary policy and the financial crisis caused by sub-prime bonds did not interrupt the $17 \%$ growth rate of money supply M2, which increased month by month. With the release of 4 trillion yuan of funds, the total amount of money continued to rise, as shown in Figure 1:

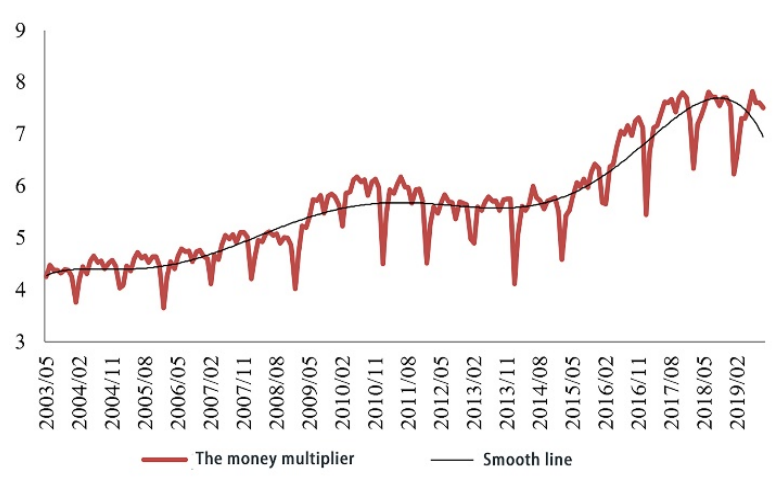

Figure 1. Money multiplier for money supply from 2003 to 2019

Zhao Zhenquan, Yu Zhen and Liu Miao (2007), Yuan Shenguo and Liu Lanfeng (2009), Wang Manyi and Liu Tongshan (2010) all took changes in the money supply as changes in monetary policy, and then analyzed the impact of monetary policy on the real economy, only from the perspective of changes in the money supply. The real economy is affected by multiple factors such as the increase of deposit reserve ratio, credit rationing, and money supply growth. Then changes in the real economy can hardly be directly correlated with changes in a single variable. Therefore, the effects of financial accelerators are difficult to predict because of the mixing of positive and negative effects. This paper attempts to add the money multiplier to further analyze the inverse effect of the money supply.

\section{Empirical analysis based on panel data}

\subsection{Data and model (data source: Wind)}

To construct the DCC_GARCH measure volatility, index return data for 'energy', 'materials', 'industry', 'optional consumption', 'daily consumption', 'health care', 'financial', 'information', 'telecommunications', 'public', 'real estate' industries from January 2009 to August 2020 are selected. To measure the robustness, the finalization index is selected as the financial index, and the social financing increment index is added to measure the model's robustness.

According to the concept of marginal expected loss (MES) proposed by Acharya et al. (2010), $r_{\mathrm{mt}}, \mathrm{r}_{\mathrm{it}}$ corresponding to the market rate of return and a corporate rate of return respectively, $\sigma \mathrm{mt}$, sit represents the conditional standard deviation of market return rate and the conditional standard deviation of enterprise return rate, $\rho_{\text {imt }}$ Represents the correlation coefficient of dynamic conditions between the market and enterprises, $\left(\varepsilon_{\mathrm{m} t}, \xi_{\mathrm{it}}\right)$ represents the perturbation term with mean 0 , variance 1 and co-variance 0 , and $\mathrm{F}$ is a two-variable distribution function with no specific distribution specified. The MES of a single enterprise is:

$$
r_{m t}=\sigma_{m t} \mathcal{E}_{m t}
$$




$$
\begin{array}{r}
r_{i t}=\sigma_{i t} \rho_{i m t} \varepsilon_{m t}+\sigma_{i t} \sqrt{1-\rho_{i m t}^{2} \zeta_{i t}},\left(\varepsilon_{m t}, \zeta_{i t}\right)^{\sim} F \\
\operatorname{MES}_{i t}^{\alpha}(C)=-\sigma_{i t} \rho_{i m t} E_{t}-1\left(\varepsilon_{m t} \mid \varepsilon_{m t} \leq C / \sigma_{m t}\right)
\end{array}
$$

Using the maximum likelihood estimation method, $\sigma_{\mathrm{mt}}, \mathrm{s}_{\mathrm{it}}, \rho_{\mathrm{imt}}$ were obtained by constructing the dcc-gjrgarch $(1,1)$ model. Copula-garch $(1,1)$ is considered to estimate the conditional correlation coefficient when it is more accurate.

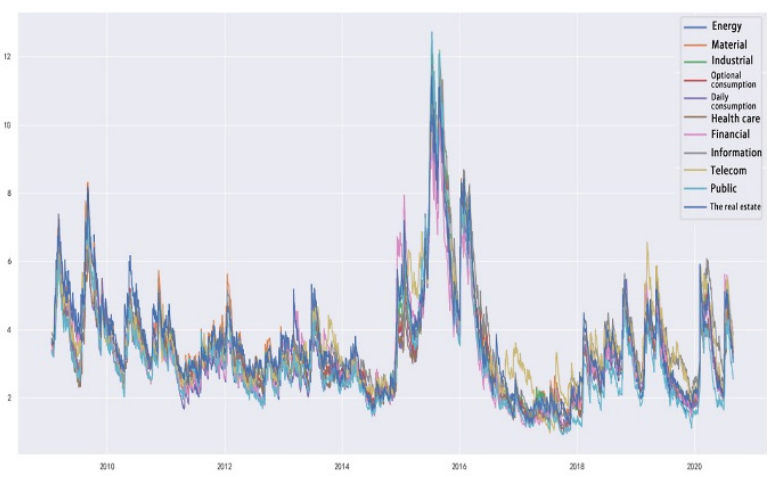

Figure 2. Volatility measures for heterogeneous industries
As can be seen from the figure, the overall trend of fluctuations among different industries is consistent, but their respective ranges have their characteristics. The leverage bull market reached its peak at the end of 2015, the delegating in 2017, and the trade war in 2019 went through numerical shocks.

\subsection{Data characteristics of variables}

Unit root test and residual co-integration test. All data are logarithmic-ally first-order stable; residual is zero-order stable, and there is a co-integration relationship between variables. Table I, data results of index returns of various industries from January 2009 to August 2020.

TABLE I. DATA RESULTS OF INDEX RETURNS OF VARIOUS INDUSTRIES FROM JANUARY 2009 TO AUGUST 2020

\begin{tabular}{|c|c|c|c|c|c|c|c|}
\hline variable & mean & $\boldsymbol{s d}$ & $\boldsymbol{m i n}$ & $\mathbf{p 5 0}$ & $\boldsymbol{m a x}$ & skewness & kurtosis \\
\hline fin & 5.833 & 0.918 & 4.651 & 5.882 & 8 & 0.849 & 2.902 \\
\hline loan & 16.34 & 5.566 & 12.3 & 14.3 & 34.44 & 2.3 & 7.307 \\
\hline $\begin{array}{c}\text { Real estate } \\
\text { ces }\end{array}$ & 3.692 & 1.749 & 1.403 & 3.293 & 11.1 & 1.739 & 7.174 \\
\hline $\begin{array}{c}\text { Public ces } \\
\text { Telecom } \\
\text { ces }\end{array}$ & 3.207 & 1.91 & 1.135 & 2.73 & 12.11 & 2.455 & 10.5 \\
\hline $\begin{array}{c}\text { Information } \\
\text { ces }\end{array}$ & 3.738 & 1.786 & 1.192 & 3.165 & 12.16 & 2.135 & 9.277 \\
\hline $\begin{array}{c}\text { Healthcare } \\
\text { CES }\end{array}$ & 3.336 & 1.715 & 1.221 & 3.018 & 10.95 & 2.201 & 9.256 \\
\hline $\begin{array}{c}\text { Financial } \\
\text { ces }\end{array}$ & 3.352 & 1.609 & 1.125 & 2.934 & 10.05 & 1.563 & 6.238 \\
\hline $\begin{array}{c}\text { Industrial } \\
\text { ces }\end{array}$ & 3.558 & 1.883 & 1.331 & 3.024 & 12.18 & 2.308 & 9.669 \\
\hline $\begin{array}{c}\text { Material } \\
\text { ces }\end{array}$ & 3.656 & 1.881 & 1.537 & 3.119 & 11.93 & 2.139 & 8.675 \\
\hline Energy ces & 3.428 & 1.726 & 1.382 & 2.947 & 10.84 & 1.884 & 7.299 \\
\hline
\end{tabular}

According to the regression results, the coefficients are all positive and significant, indicating that there is a significant financial accelerator effect. There is a significant coefficient difference, that is, there is a significant industry difference. Energy, financial enterprises themselves, and real estate are more sensitive to the financial accelerator effect and more prone to greater fluctuations.

TABLE II. ANALYSIS OF REGRESSION RESULTS ${ }^{\text {a }}$

\begin{tabular}{|l|l|l|l|l|l|l|l|l|l|}
\hline VARIABLES & fin & fin & fin & fin & fin & fin & fin & fin & fin \\
\hline \multirow{2}{*}{$\begin{array}{l}\text { Real estate } \\
\text { ces }\end{array}$} & $\begin{array}{l}1.084 * \\
* *\end{array}$ & & & & & & & & \\
\cline { 2 - 10 } & $(3.421)$ & & & & & & & & \\
\hline \multirow{2}{*}{\begin{tabular}{l} 
Public ces \\
\cline { 2 - 10 }
\end{tabular}} & $\begin{array}{l}0.780 * \\
*\end{array}$ & & & & & & & \\
\cline { 2 - 9 } & $(2.622)$ & & & & & & & \\
\hline
\end{tabular}




\begin{tabular}{|c|c|c|c|c|c|c|c|c|c|}
\hline \multirow{2}{*}{ Telecom ces } & & & $0.636 *$ & & & & & & \\
\hline & & & $(1.966)$ & & & & & & \\
\hline \multirow{2}{*}{$\begin{array}{l}\text { Information } \\
\text { ces }\end{array}$} & & & & 0.554 * & & & & & \\
\hline & & & & $(1.757)$ & & & & & \\
\hline \multirow{2}{*}{$\begin{array}{l}\text { Healthcare } \\
\text { CES }\end{array}$} & & & & & $\begin{array}{l}0.718 * \\
*\end{array}$ & & & & \\
\hline & & & & & $(2.142)$ & & & & \\
\hline \multirow{2}{*}{ Financial ces } & & & & & & $\begin{array}{l}1.065 * \\
* *\end{array}$ & & & \\
\hline & & & & & & $(3.053)$ & & & \\
\hline \multirow{2}{*}{ Industrial ces } & & & & & & & $\begin{array}{l}0.738 * \\
*\end{array}$ & & \\
\hline & & & & & & & $(2.431)$ & & \\
\hline \multirow{2}{*}{ Material ces } & & & & & & & & $\begin{array}{l}0.895 * \\
* *\end{array}$ & \\
\hline & & & & & & & & $(2.995)$ & \\
\hline \multirow{2}{*}{ Energy ces } & & & & & & & & & $\begin{array}{l}1.219 * \\
* *\end{array}$ \\
\hline & & & & & & & & & $(3.854)$ \\
\hline \multirow{2}{*}{ Constant } & $\begin{array}{l}12.34 * \\
* *\end{array}$ & $\begin{array}{l}13.84 * \\
* *\end{array}$ & $\begin{array}{l}13.97 * \\
* *\end{array}$ & $\begin{array}{l}14.23 * \\
* *\end{array}$ & $\begin{array}{l}13.95 * \\
* *\end{array}$ & $\begin{array}{l}12.77 * \\
* *\end{array}$ & $\begin{array}{l}13.72 * \\
* *\end{array}$ & $\begin{array}{l}13.07 * \\
* *\end{array}$ & $\begin{array}{l}12.16^{*} \\
* *\end{array}$ \\
\hline & $(9.536)$ & $(12.48)$ & $(10.44)$ & $(10.66)$ & $(11.10)$ & $(9.861)$ & $(11.25)$ & $(10.65)$ & $(10.03)$ \\
\hline Observations & 91 & 91 & 91 & 91 & 91 & 91 & 91 & 91 & 91 \\
\hline R-squared & 0.116 & 0.072 & 0.042 & 0.034 & 0.049 & 0.095 & 0.062 & 0.092 & 0.143 \\
\hline
\end{tabular}

\section{Take the steel industry as an example}

\subsection{Data and model}

The panel data of the steel enterprises listed in Shanghai and Shenzhen stock Exchanges from June 2006 to December 2018 are sorted by assets, and the first and last three are selected to verify the impact of financial acceleration on enterprises of different sizes and obtain financial data such as asset A, liability D and investment I. Investment amount I and net asset $\mathrm{Na}$ were seasonally adjusted with X11 (adI and adNa after adjustment; Eviews6.0 Seasonal adjustment - X11). Besides, the monthly data of money supply M2, consumer price index CPI, and deposit reserve ratio RRR (large Banks) are all converted into quarterly data. M2/CPI is adjusted to the actual money supply, but M2 is still used to represent the actual money supply below, and the deposit reserve ratio is converted into the money multiplier $\mathrm{MC}=1 / \mathrm{RRR}$. Taking into account the impact of net assets on investment or the learning effect in investment, $\mathrm{Na}$, the net assets lagging one quarter, is selected; Considering the time lag of monetary policy, the money supply M2 with a lag of 2 quarters and the deposit reserve ratio RRR with a lag of 4 quarters are taken here. Based on the opposite direction of the above changes in the money supply and the deposit reserve ratio, namely, considering separately the impact of the changes in the money supply and the deposit reserve ratio on enterprise investment, the following model is proposed: a. T-statistics in control and control $(\mathrm{P}<0.01),{ }^{* *} \mathrm{P}<0.05,{ }^{*} \mathrm{p}<0.1$

$$
\ln I_{i t}=c_{i t}+\alpha_{i t} \ln N a(-1)+\beta_{i t} \ln m_{2}(-2)+\mu_{i t}
$$

$$
\ln I_{i t}=c_{i t}+\alpha_{i t} \ln N a(-1)+\chi_{i t} \ln m c(-4)+\mu_{i t}
$$

\subsection{Data inspection and regression}

\subsubsection{Unit root test and residual co-integration test.}

All data are logarithmic ally first-order stable, residual is zero-order stable, and there is a co-integration relationship between variables. Table III:

TABLE III. ADF FIRST-ORDER DIFFERENCE VALUE TEST (ZERO-ORDER RESIDUAL)

\begin{tabular}{|c|c|c|c|}
\hline \multirow{2}{*}{} & \multirow{2}{*}{ Variable } & \multicolumn{2}{|c|}{ ADF test } \\
\cline { 3 - 4 } & & $\boldsymbol{t}$-Statistic & Prob. \\
\hline Large iron & $\ln \mathrm{I}$ & 4.768873 & 0.0084 \\
\cline { 2 - 4 } $\begin{array}{c}\text { and steel } \\
\text { enterprise }\end{array}$ & $\ln \mathrm{Na}$ & 2.807541 & 0.0140 \\
\cline { 2 - 4 } $\begin{array}{c}\text { Small iron } \\
\text { and steel } \\
\text { enterprise }\end{array}$ & $\ln \mathrm{I}$ & 3.752791 & 0.0138 \\
\cline { 2 - 4 } & $\ln \mathrm{Na}$ & 2.845618 & 0.0262 \\
\cline { 2 - 4 } Monetary & $\mathrm{U}$ (residual) & 3.329539 & 0.0046 \\
\cline { 2 - 4 } policy & $\ln \mathrm{M} 2$ & 2.966915 & 0.0158 \\
\cline { 2 - 4 } & $\ln \mathrm{mc}$ & 3.684560 & 0.0566 \\
\hline
\end{tabular}

\subsubsection{Hausman test and regression analysis}

The results of the residual co-integration test show that there is a long-term stable equilibrium relationship 
between the three variables, and the regression residual of the equation is stable, and the original equation can be returned on this basis. All Hausman tests reject the null hypothesis, so the random effect model is used for estimation. The regression results are shown in Table IV.

TABLE IV. REGRESSION ANALYSIS RESULTS OF THE IMPACT OF MONETARY POLICY ON CORPORATE NET WORTH AND INVESTMENT

\begin{tabular}{|c|c|c|c|c|c|c|}
\hline & Hausman fe & Variable & Coef. & $Z$ & Prob. & $R-s q$ \\
\hline \multirow{6}{*}{$\begin{array}{l}\text { Large iron } \\
\text { and steel } \\
\text { enterprise }\end{array}$} & \multirow{6}{*}{$\begin{array}{c}\text { Chi2 }(1)= \\
5.57 \\
\text { Prob }>\text { chi2 } \\
=0.0183\end{array}$} & $\ln \mathrm{Na}$ & 1.19576 & 13.23 & 0.0040 & \multirow{3}{*}{0.8234} \\
\hline & & $\ln \mathrm{M} 2$ & 2.276241 & 10.38 & 0.0014 & \\
\hline & & $\mathrm{c}$ & 14.79454 & 7.82 & 0.000 & \\
\hline & & $(\ln \mathrm{Na})$ & 1.193004 & 10.56 & 0.000 & \multirow{3}{*}{0.7275} \\
\hline & & (ln mc) & 1.537904 & 7.20 & 0.000 & \\
\hline & & (c) & 7.31649 & 5.26 & 0.000 & \\
\hline \multirow{6}{*}{$\begin{array}{l}\text { Small iron } \\
\text { and steel } \\
\text { enterprise }\end{array}$} & \multirow{6}{*}{$\begin{array}{c}\text { Chi2 }(1)= \\
0.11 \\
\text { Prob }>\text { chi2 } \\
=0.7378\end{array}$} & $\ln \mathrm{Na}$ & 1.913952 & 5.39 & 0.000 & \multirow{3}{*}{0.3795} \\
\hline & & $\ln \mathrm{M} 2$ & 0.8798319 & 2.40 & 0.016 & \\
\hline & & $\mathrm{c}$ & 16.06625 & 3.29 & 0.001 & \\
\hline & & $(\ln \mathrm{Na})$ & 1.885324 & 5.40 & 0.000 & \multirow{3}{*}{0.3783} \\
\hline & & (ln mc) & 0.6681212 & 2.38 & 0.017 & \\
\hline & & (c) & 7.168195 & 3.40 & 0.001 & \\
\hline
\end{tabular}

The regression equation is:

$$
\begin{aligned}
& \ln I_{i t}=14.79+1.20 \ln N a(-1)-2.28 \ln m_{2}(-2)(6) \\
& \ln I_{i t}=-7.32+1.19 \ln N a(-1)+1.54 \ln m c(-4)
\end{aligned}
$$$$
\ln I_{i t}=-16.07+1.91 \ln N a(-1)+0.88 \ln m_{2}(-2)
$$$$
\ln I_{i t}=-7.17+1.89 \ln N a(-1)-0.67 \ln m c(-4)
$$

Equation (6) is the impact of money supply on large steel enterprises. Equation (7) is the impact of the deposit reserve ratio on large steel enterprises. Equation (8) is the impact of money supply on small steel enterprises, equation (9) is the impact of deposit reserve ratio on small steel enterprises.

\subsubsection{Empirical conclusions}

\subsubsection{Look at the impact of changes in the money supply alone.}

As can be seen from the coefficient of equation (6) and (8), when the real money supply increases by 1 unit, the investment of large iron and steel enterprises decrease by 2.28 units. On the contrary, the investment of small iron and steel enterprises changes by 0.88 units, which is smaller than that of large iron and steel enterprises.

\subsubsection{Changes in the Deposit reserve ratio (Changes in the Money Multiplier)}

As can be seen from the coefficients in equation (7) and (9), the monetary multiplier decreases by one unit, and the investment of large iron and steel enterprises decreases by 1.54 units. Small iron and steel enterprises increased their investment by 0.67 units, and the change rate was smaller than that of large steel enterprises.

According to the financial accelerator effect theory, changes in the money supply should follow $\mathrm{M} \uparrow \rightarrow \mathrm{R} \downarrow \rightarrow$ $\mathrm{P} \uparrow \rightarrow \mathrm{Na} \uparrow \rightarrow \mathrm{Loan} \uparrow \rightarrow(\mathrm{I} \uparrow \rightarrow \mathrm{Y} \uparrow)$, but the actual situation and the data showed: the money supply increases, due to fight inflation, the real interest rate market, and nominal interest rates are on the rise, prices rise, large steel enterprises rise in net asset value, but the investment is falling, rather than the financial accelerator effect of investment and Loan cycle rise. The actual situation is as follows:

$\nearrow$ Loan $\uparrow$ (prosperous company, large-scale)

$\rightarrow(\mathrm{I} \downarrow \rightarrow \mathrm{Y} \downarrow)$

$\mathrm{M} \uparrow, \mathrm{R} \uparrow$

$\searrow$ Loan $\downarrow \quad$ (restrained company, small $) \rightarrow(\mathrm{I} \uparrow \rightarrow$ $\mathrm{Y} \uparrow)$

Large iron and steel enterprise investment reduce can be thought of as tightening of monetary policy, but under the tightening monetary policy, the bank didn't like Bernanke, to accelerate the theory of "clearing" ahead of time, also didn't like Bacchetta reduction theory according to enterprise's financial leverage and preferences for small business loans, and large iron and steel enterprises are much bigger than the impact on small iron and steel companies, seems to prevent excess capacity of environment, small iron and steel enterprises have more space. While plenty of literature in the real estate industry found that financial accelerator conclusive evidence, this paper argues that the reason for this is the case, in the process of economic contraction, financial not chose a better enterprise financial leverage, but choose the asset bubble is expected to continue to grow, the financial accelerator effect on some areas, the actual situation is more likely to be like this:

$\mathrm{M} \uparrow, \mathrm{R} \uparrow \rightarrow$ Loan $\uparrow \quad$ (bubble company, SOB $) \rightarrow(\mathrm{I} \uparrow \rightarrow$ $\mathrm{Y} \uparrow) \rightarrow$ Debt Crisis $>>>\mathrm{Na} \downarrow \rightarrow(\mathrm{I} \downarrow \rightarrow \mathrm{Y} \downarrow)$

$\searrow$ Loan $\downarrow \quad$ (frozen company) $\rightarrow(\mathrm{I} \downarrow \rightarrow \mathrm{Y} \downarrow)$

When the debt crisis detonates the overheated industry, the new economic stimulus will start and enter the next cycle, frozen company and Bubble Company will be activated simultaneously, but after entering the overheating expectation once again, the policy will be reversed, and the financial accelerator effect will 
gradually focus on the overheated area for a longer time, bringing more economic fluctuations.

\section{Research conclusions and implications}

The above research shows that there are obvious industry differences among financial accelerators. Energy, financial enterprises themselves, and real estate are more sensitive to the effect of financial accelerators and more prone to large fluctuations. Different industries have different accelerator effects, which means different procedures for the occurrence of risks when exposed to external shocks. In other words, the same monetary policy may cause different economic fluctuations in different industries. Insensitive industries, it is necessary to release monetary policy more cautiously and make a pro-cyclical adjustment.

China's financial accelerator is more focused on sectors where growth is expected to be bubbly, such as real estate, which continues to overheat in the face of tighter policy, triggering a bigger debt crisis and greater economic volatility. Therefore, the government can adopt a differentiated monetary policy paradigm when making policies, taking into account the different influences of financial accelerators in different industries and enterprises of different specifications.

\section{References}

1. Bernanke, Ben; Getler, Mark and Gilchrist, Simon. The Financial Accelerator in a Quantitative Business Cycle Framework [M].The Handbook of Macroeconomics. Ed. By J.B.T Aylor, and M. W. Oodford, 1999:1341-1393.

2. Kiyotaki, Nobuhiro, and Wright, Randall. A Contribution to Pure Theory of Money [J]. The American Economic Review. 1997.53(2)I. S. Jacobs and C. P. Bean, "Fine particles, thin films and exchange anisotropy," in Magnetism, vol. III, G. T. Rado and H. Suhl, Eds. New York: Academic, 1963, pp. 271-350.

3. Kiyotaki, Nobuhiro and Moore, John. Credit Cycles [J]. The Journal of Political Economy. 1991.105(2):211-248

4. Bacchetta, Philippe Caminal, and Ramon, Do Capital Market Imperfections Exacerbate Output Fluctuations? [J]. European Economic Review. 2000,44 (3)

5. Cao Yongqin. Defects in Financial Market: Accelerator or Buffer [J]. Economist, 2009.10:92-98

6. Hou Kun. Summary of Theoretical Research on Financial Accelerators in Economic Fluctuations [J]. Hainan Finance, 2011 (4) : 11-14

7. Shao Suxue, Yuan Tianyong, Wang Chuan.A Review of Theoretical Research on Financial Accelerators [J]. Times Finance, 2011 (4) : 71
8. Zhao Zhenquan, Yu Zhen, Liu Miao. Does the financial accelerator effect exist in China?[J]. Economic Research, 2007.6:28-38

9. Yuan Shenguo, Liu Lanfeng.Industry Difference Analysis of the Financial Accelerator Effect of Monetary Policy in China [J]. Shanghai Finance, 2009(3): 36-39.

10. Wang Manyi, Liu Tongshan.Financial Accelerator Effect and Regulation of China's Real Estate Industry -- An Empirical Study based on Panel Data [J].Finance and Economics, 2010(7): 88-92.

11. Wang Chuan, Li Xin, Zhou Zhenfeng. Credit Channel of Monetary policy: China's Economic Cycle Analysis based on the "Financial Accelerator Model" [J].International Finance Studies, 2011.1:3543 